\title{
Наталья ШУБНИКОВА-ГУСЕВА
}

\section{«ЗРЕНИЕ МОЕ ПЕРЕЛОМИЛОСЬ...»: ЕСЕНИН ОБ АМЕРИКЕ}

\begin{abstract}
Аннотация: В статье рассматривается динамика восприятия образа Америки в произведениях С.А. Есенина разных лет. Основное место занимает анализ драматической поэмы «Страна Негодяев» (1922-1923) и очерка «Железный Миргород» (1923). Эти произведения были написаны под впечатлением пребывания поэта в этой стране в 1922-1923 гг. вместе с женой, американской танцовщицей Айседорой Дункан. Используется текстологический анализ рукописных источников этих произведений. Раскрывается диалогизм и шекспировский подтекст «Страны Негодяев», а также полемический диалог Есенина в «Железном Миргороде» с поэмой В.В. Маяковского «150 000 000» и статьями о Париже.

Особое внимание уделяется отличию образа Америки, отраженного в этих произведениях, от образа этой страны в повести Есенина «Яр» (1916), поэме «Инония» (1918), статье «Ключи Марии» (1918) и изменению взгляда Есенина на будущее России под впечатлением от пребывания в Америке, от мощи американской цивилизации.
\end{abstract}

Ключевые слова: С.А. Есенин, Америка, «Страна Негодяев», «Железный Миргород» (1923), У. Шекспир, В.В. Маяковский «150 000 000», статьи о Париже.

() 2017 Наталья Игорьевна Гусева (Шубникова-Гусева) (доктор филол. наук, главный научный сотрудник, Институт мировой литературы им. А.М. Горького Российской академии наук, Москва) shubnikova-gus@ mail.ru 
UDC $82-821$

DOI 10.22455/2541-7894-2017-3-247-269

\title{
Natalia SHUBNIKOVA-GUSEVA
}

\author{
"MY SIGHT BROKE...": \\ ESENIN ABOUT AMERICA
}

\begin{abstract}
The article deals with the changes in Esenin's image of America as it is represented in his works of various years. The main attention is focused on the analysis of the dramatic poem "The Country of Scoundrels" (1922-1923) and the essay "The Iron Mirgorod" (1923). These works were written under the impression of the poet's travel to the States in 1922-1923 together with his wife, the American dancer Isadora Duncan. The research is based on the textual analysis of the manuscript sources and is aimed at revealing dialogism and Shakespearean subtext in "The Country of Scoundrels", as well as Esenin's polemic with Vladimir Mayakovsky's articles about Paris and the poem " 150000000 " in "The Iron Mirgorod".

Special emphasis is laid on the difference between Esenin's image of America in the above mentioned works and in the story "Yar" (1916), the poem "Inonia" (1918) and the article "The Keys of Mary" (1918) that allows to trace the changes of Esenin's view on the future of Russia caused by his stay in America and the impression the powerful American civilization made on him.

Key words: S.A. Esenin, America, "The Country of Scoundrels", "The Iron Mirgorod" (1923), Shakespeare, V. Mayakovsky "150 000 000", Mayakovsky "s articles about Paris.
\end{abstract}

(C) 2017 Natalia I. Guseva (Shubnikova-Guseva) (A.M. Gorky Institute of World Literature, Russian Academy of Science, Moscow; Chief scientific Researcher, Doctor Hab. in Philology) shubnikova-gus@mail.ru 
«Мертвящему лязгу Америки, “электрическому восходу”, “глухой хватке ремней” Есенин посвятил немало вдохновенных строк». Так писал критик А.К. Воронский в статье «Сергей Есенин», где называл поэта «одним из самых тонких, нежных лириков современности» ${ }^{1}$. Вопрос о восприятии певцом деревянной Руси крупнейшей индустриальной державы мира ставился исследователями преимущественно в плане воплощения всего того, что «пугало патриархального крестьянина в чуждом ему городе» ${ }^{2}$. При этом образ Америки в произведениях Есенина рассматривался, как правило, в одном ряду с произведениями В.Г. Короленко, М. Горького и В. Маяковского ${ }^{3}$. Достаточного внимания полемике со своими предшественниками, которая была характерной чертой творческой манеры Есенина и ярко проявилась в своеобразии воплощения им американской темы, особенно в 1920 -е гг. ${ }^{4}$, не уделялось, и поэтому художественная индивидуальность поэта в полной мере не раскрывалась. Между тем, Есенин, прожив в Америке четыре месяца, объездив, по его собственным словам, все штаты, по возвращении из зарубежного путешествия (куда он отправился вместе со своей женой, знаменитой американской танцовщицей А. Дункан) признал: «Зрение мое переломилось», - и именно под влиянием американских впечатлений.

Как же изменилось представление Есенина об Америке после знакомства с этой страной? И в чем состоял тот новый взгляд на свою страну и путь ее развития, который сложился у поэта после живого знакомства с Америкой? Попробуем рассмотреть эти вопросы, анализируя два произведения, написанных почти одновременно, - «Страну Негодяев» (1922-1923) и «Железный Миргород» (1923), привлекая данные текстологии.

Отношение Есенина к Америке, сложное и противоречивое, связанное с мыслями о судьбе своего народа, претерпело замет-

${ }^{1}$ Воронский А.К. Литературные силуэты. Сергей Есенин // Красная новь. 1924, № 1. C. $278,289$.

${ }^{2}$ Кубанев Н.А. Образ Америки в русской литературе (из истории русскоамериканских литературных связей конца XIX - первой половины XX века). М.: Гуманит. ун-т; Арзамас: Арзамас, гос. пед. ин-т, 2000. С. 209.

3 Арустамова А.А. Тема Америки в русской литературе XIX в.: дис. ... докт. филол. наук. Пермь, 2010.

${ }^{4}$ Шубникова-Гусева Н.И. Поэмы Есенина: От «Пророка» до «Черного человека»: Творческая история, судьба, контекст и интерпретация / Н.И. Шубникова-Гусева. М.: «Наследие», 2001; Шубникова-Гусева Н.И. Маяковский и Есенин: диалог поэтов // Творчество В.В. Маяковского. Вып. 2: Проблемы текстологии и биографии / Отв. ред. В.Н. Терехина. М.: ИМЛИ РАН, 2014. С. 198-222; Еременко Н.А. Американская тема в творчестве С.А. Есенина: поэтика и контекст: дис. ... канд. филол. наук. М., 2015. 
ную эволюцию за десять лет. В 1916-1918 гг. образ неизвестной страны сложился по сообщениям в печати и книгам. Впервые упоминание Америки в творчестве Есенина встречается в повести «Яр» (1916) в рассказе-сказке деда Иена:

Имелася у одного попа собака, такая дотошная, ин всех кур у дьякона потяпала. Сгадал поп собаку поучить говорить по-человечьи. Позвал поп работника Ивана и грить ему так: “Пожжай, балбес, в Амирику, обучи пса по-людски гуторить. Вот тебе сто рублев, ин нехватки, так займи там. У меня оттулева много попов сродни есть"

Сюжет новеллистической сказки о поповской собаке зафиксирован в ряде областей России и отмечен комментатором «Яра» в Полном собрании сочинений С.А. Есенина [5, с. 370; комм. Е.А. Самоделовой]. Но еще важнее то, что в этом эпизоде Америка предстает как страна безграничных возможностей, место, где можно даже пса научить разговаривать. Люди в Америке в представлении деда Иена обладают необычными способностями. Сходная мысль звучит в романе Достоевского «Братья Карамазовы», где Митя, размышляя о своем бегстве в Америку, выражает уверенность в том, что там его внешность смогут изменить до неузнаваемости: «недаром же они механики» ${ }^{6}$. В письме к Ширяевцу от 24 июня 1917 г., где поэты крестьянской купницы противопоставляются «питерским литераторам», Есенин называет их западниками, «им нужна Америка, а нам в Жигулях песня да костер Стеньки Разина» ${ }^{7}$.

Символом старого мира и воплощением бездуховности становится Америка в поэме «Инония» и статье «Ключи Марии», написанных в 1918 г. В «Инонии» Есенин называет ее «отколотая половина земли» ${ }^{8}$, потому что она расположена на отдельном ма-

${ }^{5}$ Есенин С. Полн. собр. соч. / Ин-т мировой лит. РАН / Гл. ред. Ю.Л. Прокушев. Т. 5 / Сост. и коммент.: А.Н. Захаров, С.П. Кошечкин, Е.А. Самоделова, С.И. Субботин, Н.Г. Юсов. М.: Наука - Голос. 1997. С. 78. Далее этот том цит. в тексте с указ. номера тома и страниц.

${ }^{6}$ Достоевский Ф.М. Братья Карамазовы // Полн. собр. соч. Ф.М. Достоевского. В 12 т. СПб., Изд. А.Ф. Маркса. 1895. Прилож. к журналу «Нива». Т. 12. C. 906.

${ }^{7}$ Есенин С. Полн. собр. соч. / Ин-т мировой лит. РАН / Гл. ред. Ю.Л. Прокушев. Т. 6 / Сост. и общ. ред. - С.И. Субботин; Подгот. текстов и текстологич. коммент.: Е.А. Самоделова, С.И. Субботин; Реальный коммент.: А.Н. Захаров, С.П. Кошечкин, С.С. Куняев, Г. Маквей, Ю.А. Паркаев, Ю.Л. Прокушев, Т.К. Савченко, М.В. Скороходов, С.И. Субботин, Н.И. Шубникова-Гусева, Н.Г. Юсов. М.: Наука - Голос. 1999. С. 95. Далее этот том цит. в тексте с указ. номера тома и страниц.

${ }^{8}$ Есенин С. Полн. собр. соч. / Ин-т мировой лит. РАН / Гл. ред. Ю.Л. Прокушев. Т. 2 / Подгот. текстов и коммент. - С.И. Субботин. М.: Наука; Голос. 1997. С. 65. Далее этот том цит. в тексте с указ. номера тома и страниц. 
терике и противостоит духовному преобразованию мира. С Америкой Есенин связывает такие образы, как «железные корабли», «чугунная радуга», «гранит», «шляпки гвоздиные», «лава стальной руды», «проволочные лучи», «тыны и заборы» - т.е. образы, напрямую связанные с тем, что сковывает человека, лишает его свободы. В «Инонии» американская бездуховность образно олицетворяется с приметами большого города и городской цивилизации.

В одной из многочисленных статей об «Инонии» «Мессианство в новой русской поэзии: “Пророк Есенин Сергей”» критик А. Киселев пишет:

Обращаясь к старому миру, олицетворенному в виде Америки, технически мощной, но слабой своею бездушностью и безверием, поэт еще раз ставит русскую тему о примате религиозно-этических ценностей над ценностями материальной культуры. Эта культура несет в себе зародыши гибели, опустошения души, упирающейся в бессмысленное накопление [...], ибо «проволочные лучи», которыми культура опутала землю, «не осветят пришествия» нового Бога 9 .

Критик справедливо замечает, что поэма «Инония» не содержит в себе конкретных предсказаний, но передает очень важную мысль, что «мы стоим на великом переломе, что в душе нового человека назревают новые ценности, без которых “нечем жить” в этой основной мысли "Инонии" ее значение, переходящее за грани текущего дня» ${ }^{10}$.

Неслучайно, в статье «Ключи Марии», которую поэт называл «теорией искусства», также появляется негативная характеристика Америки и американского пути развития:

Звериные крикуны, абсолютно безграмотная критика и третичный период идиотического состояния городской массы подменили эту завязь безмозглым лязгом железа Америки и рисовой пудрой на выпитых щеках столичных проституток. Единственным расточительным и неряшливым, но все же хранителем этой тайны была полуразбитая отхожим промыслом и заводами деревня. [5, с. 201]

В определенной мере Америка в эти годы становится символом городской цивилизации, катастрофичной, по мнению Есенина, для России и русского сознания. Тем не менее, и в те годы, как заметил А.К. Воронский, Есенин предпочитал «асфальт городских

${ }^{9}$ Киселев А. Мессианство в новой русской поэзии: «Пророк Есенин Сергей» // Путь, Гельсингфорс, 1921, 31 марта и 1 апреля, №№ 32 и 33. Цит. по: Летопись жизни и творчества С.А. Есенина: В 5 т. Т. 3, кн. І. / Гл. ред. А.Н. Захаров; Сост.: В.А. Дроздков, А.Н. Захаров. С участием М.В. Скороходова, Т.К. Савченко, Н.И. Шубниковой-Гусевой и др. М.: ИМЛИ РАН. С. 81.

10 Там же. 


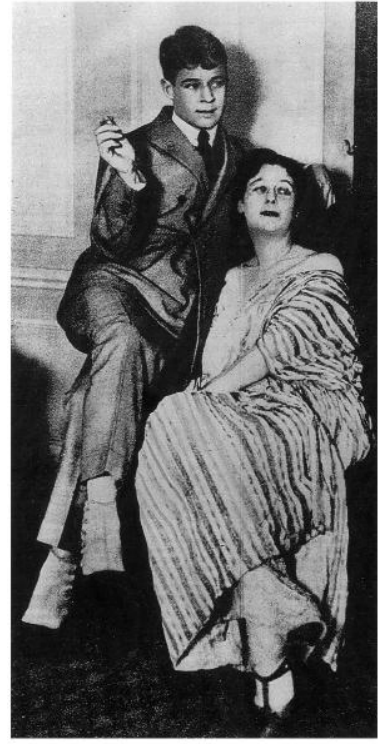

А. Дункан и С.А. Есенин на пароходе "Paris" 1 окт. 1922 г.

(Собр. Г. Маквея)

улиц и электрическое освещение родной лучинушке» ${ }^{11}$. Так критик пытался доказать, что Есенин «двойственен, расколот, дисгармоничен, подвержен глубоко различным настроениям, часто совсем противоположным» ${ }^{12}$. На самом деле в этих противоречиях отражались противоречия самой действительности, в которой жил поэт. Как мы увидим, в дальнейшем, особенно в поэме «Страна Негодяев», отношение Есенина к образу Америки и к американскому пути развития претерпит существенные изменения.

Есенин рассказывал И.И. Шнейдеру, что на борту парохода по пути в НьюЙорк готовил приветственную речь, в которой хотел говорить американцам «о великих русских идеях и работать для сближения двух великих стран». Поэт хотел сказать, что душа России и душа Америки в состоянии понять одна другую». «Однако пришлось не речи произносить, а объясняться с полицейским чиновником, получившим из Вашингтона указание не впускать в страну ни Айседору, ни Есенина ввиду их “красных симпатий”»13. Есенин стремился попасть в Америку, страну Колумба, Эдисона и Эдгара По. Как известно, творчество американского поэта Э. По поэт особенно ценил, сравнивал себя с ним и явно не без оглядки на гениального «Ворона» (в пер. К. Бальмонта) писал своего «Черного человека». Из современных поэтов Есенин отметит «крупный талант» еврейского поэта Мани-Лейба, «красивые таланты» от Д.Н. Гофштейна до П.Д. Маркиша [5, с. 172]. Диалоги Есенина с американскими поэтами заслуживают специального исследования. Однако стоит напомнить, что Есенин был знаком с творчеством Уолта Уитмена и работами о нем К.И. Чуковского и «неоднократно утверждал, что Маяковский весь идет из Уитмана ${ }^{14}$. Уолт Уитмен был любимым поэтом Дункан. Вы-

${ }^{11}$ Воронский А.К. Литературные силуэты. Сергей Есенин. С. 280.

12 Там же. С. 281.

${ }^{13}$ См.: Зверев A. Сергей Есенин в Америке // В мире Есенина. Сб. статей. М.: Сов. писатель. 1986. С. 361-362.

${ }^{14} \mathrm{O}$ том, что Маяковский «весь идет от Уитмена», Есенин говорил И.Н. Розанову 26 февраля 1921 г., см.: Летопись жизни и творчества С.А. Есенина. T. 3. Кн. 1. С. 58. 
ступая на первом вечере танца в Нью-Йорке в Карнеги-холл 7 октября 1922 г. перед трехтысячным, вдохновленным залом, Дункан представила публике Есенина и назвала его «русским Уолтом Уитменом России». В своем выступлении она сказала: «Любите Россию, ибо в России есть все, чего нет в Америке, точно так же, как в Америке есть все, чего нет в России. День, когда Россия и Америка придут к взаимопониманию, станет началом новой эпохи для человечества» ${ }^{15}$.

Не все надежды на путешествие по Америке оправдались, но все же впечатления были настолько сильны, что Есенин дважды кардинально изменил сюжет драматической поэмы «Страна Негодяев», над которой начал работать еще до поездки, и задумал серию заметок об этой стране. Однако, столкнувшись с препятствиями в публикации, написал только «Железный Миргород».

Особенно сложной на пути к читателю оказалась судьба поэмы «Страна Негодяев».

По первоначальному замыслу, - который И.И. Старцев относит к зиме 1921-1922 гг., - поэма должна была широко охватить революционные события в России с героическими эпизодами гражданской войны. Главными действующими лицами в поэме должны были быть Ленин, Махно и бунтующие мужики. Первоначальный замысел этой поэмы у него разбрелся по отдельным вещам: «Гуляй-поле» и «Страна негодяев» в существующем тексте ${ }^{16}$.

Перестройка сюжета произошла во время зарубежного путешествия Есенина с А. Дункан (май 1922 - авг. 1923). В «Стране Негодяев» особенно заметны американские впечатления от «ужаснейшего царства мещанства», где «в страшной моде господин доллар» [6, с. 139]. В зарубежных письмах поэта конца 1922 - нач. 1923 гг. возникает праобраз метафоры «скотный двор» как формулы человеческой жизни в «Стране Негодяев» ${ }^{17}$, обыгрываются образы из поэмы В.В. Маяковского «150 000 000», упоминаются имена И.А. Аксенова, в то время директора ГИТИСа, занятого вместе с Маяковским и Мейерхольдом переделкой шекспировского «Гамлета» в духе современного политического шоу, эстрадной

${ }^{15}$ См. газ. «The New York Tribune», 1922, 9 окт. Цит. по: Летопись жизни и творчества С.А. Есенина. Т. 3. Кн. II / Сост. А.Н. Захарова, С.И. Субботина. Науч. ред. Н.И. Шубниковой-Гусевой. М.: ИМЛИ РАН, 2008. С. 202.

${ }^{16}$ С.А. Есенин в воспоминаниях современников. В 2 т. / Статья, сост. и примеч. А.А. Козловского. Т. 1. М.: Худож. литература. 1986. С. 414.

${ }^{17}$ Есенин С. Полн. собр. соч. / Ин-т мировой лит. РАН / Гл. ред. Ю.Л. Прокушев. Т. 3 / Сост. и подгот. текстов Н.И. Шубникова-Гусева; Коммент.: Е.А. Самоделова, Н.И. Шубникова-Гусева. М.: Наука; Голос. 1998. С. 61. Далее этот том цит. в тексте с указ. номера тома и страниц. 
певицы Изы Кремер и, наконец, Шекспира, - все это так или иначе полемически отзовется в «Стране Негодяев». Судя по воспоминаниям друга Есенина, Вен. Левина, который слышал поэму в авторском исполнении на вечере М.Л. Брагинского 27 января 1923 г. в Нью-Йорке и имел автограф ее раннего варианта, до конца января 1923 г. в поэме речь шла о продовольственном, а не о золотом поезде.

Третье и окончательное изменение сюжета поэмы было принято в Нью-Йорке и связано с появлением нового персонажа Рассветова, сопровождающего золотой эшелон - Экспресс № 5. Об этом говорит авторская датировка монолога Рассветова, данная в первой публикации ${ }^{18}$ - «14 февраля 1923 г. Нью-Йорк». Явная ошибка, допущенная Есениным в части даты (уже 3 февраля поэт покинул Нью-Йорк), говорит о том, что монолог Рассветова был доработан и датирован, скорее всего, при подготовке отрывков из поэмы к печати в 1924 г.

Историко-литературный и текстологический анализ поэмы показывает, что время окончательного завершения «Страны Негодяев», и в том числе монолога Рассветова, связано с шумным и скандальным процессом над видным большевиком А.М. Краснощековым (Председатель правительства Дальневосточной республики - 1921, заместитель наркома финансов, член Президиума ВСНХ и Председатель правления Промбанка - 1922-1923). Как убедительно доказали обнаруженные документы и факты, видная и известная фигура того времени, на которой сходятся основные реалии текста: американские («биржевые трюки», проповедь американского образа жизни) и дальневосточные аналогии (в том числе денежная купюра «ходи»), самая непосредственная связь с финансовым миром и черты биографии (Краснощеков родился в Киеве и долгое время жил в Америке), была в поле зрения Есенина и послужила прототипом одного из главных героев «Страны Негодяев» - Рассветова.

Есенин, который обладал поразительной способностью схватывать самые яркие, знаковые приметы времени, отраженные в газетных и журнальных публикациях тех лет, знал о Краснощекове не только по газетам и циркулирующим в городе слухам (о романе с Лилей Брик и процессе над первым банкиром говорила вся Москва) и от близких ему людей (Краснощеков дружил с А. Дункан, близкая подруга бывшей жены поэта 3.Н. Райх, 3.Н. Гейман, жена В.М. Левина, в 1921 г. работала ответственным секретарем Дальневосточного правительства), но и по публикациям в газетах (март 1924). Доказательством того, что монологи Рассветова были

${ }^{18}$ Газ. «Бакинский рабочий». 1924, 29 сент. 
окончательно доработаны во время процесса над Краснощековым, служат переклички текста поэмы и газетных публикаций тех лет, а также время публикации монолога (сент. 1924) ${ }^{19}$.

Рассветов, ставший одним из главных героев драматической поэмы, рассматривался в работах советских исследователей как положительный персонаж, и авторская позиция Есенина чаще всего отождествлялась с рассветовской. Тем более, что американская тематика монологов Рассветова сближает «Страну Негодяев» с «Железным Миргородом». «Владычество доллара, - пишет Есенин об американцах в статье об Америке, - съело в них все стремления к каким-либо сложным вопросам. Американец всецело погружается в "Business" и остального знать не желает» [5, c. 170]. «Сила железобетона, громада зданий стеснили мозг американца и сузили его зрение» [5, с. 172]. Во вдохновенных монологах Рассветова об Америке, которая стала символом Мировой Биржи, ее оценки в этой части совпадают с оценками Есенина:

Эти люди — гнилая рыба,

Вся Америка - жадная пасть...

Вот она Мировая Биржа!

Вот они — подлецы всех стран. [3, с. 73-74]

Однако других взглядов и поступков Рассветова Есенин, как мы убедимся, явно не одобряет. Весь «Персонал» «Страны Негодяев» находится в сложных отношениях друг к другу и к автору. Каждое действующее лицо утверждает своеобразную позицию, в которой есть немало общего с другими, в том числе и с автором. В этом диспуте автор в конечном счете не разделяет взглядов комиссара золотых приисков. Не разделяет он и взглядов Номаха и не выступает под его личиной подлинным героем поэмы. Эта мысль подчеркнута в названии поэмы.

«Страна Негодяев» - поэма без героя. Есенин здесь использует особый прием: его собственная речь как бы отражается в речевых характеристиках героев поэмы, вступая с каждым из них в диалог. Получается соединение своего и чужого, своеобразное образное ряженье. Недаром переодевание является одним из важных структурных элементов действия. Чтобы уйти от чекистов, Номах советует Барсуку: «Перерядись». Тот одевается в костюм стекольщика. Номах обманывает преследователей и наряжает сыщика Литза-Хуна в свой костюм, а сам наряжается в костюм китайца. Истинная суть персонажей, особенно Рассветова, скрыта за красивыми идейными словами. «Все вы носите овечьи шкуры и

${ }^{19}$ Подробнее см. в кн.: Шубникова-Гусева Н.И. Поэмы Есенина: С. 189-289. 
мясник пасет для вас ножи», - говорит Номах защитнику коммуны Замарашкину. Вся трагедия выглядит как сатирический фарс, в котором «мир идейных дел и слов» вывернут наизнанку и показана его бездуховная сущность и высокопарная видимость.

Не соглашаясь с позицией своих персонажей, Есенин как бы направляет зеркалом солнечные «зайчики», отмечая героев портретным сходством с самим собой или вплетая цитаты из собственных произведений в речь своих персонажей. Таким сходством поэт только подчеркивает различие. «Отражаясь» в речи, поэт вступает с ними в диалог. Прием зеркального отражения используется, как обычно бывает у Есенина, чтобы подчеркнуть иную суть своих взглядов и ввести многозначный подтекст ${ }^{20}$. Есенин переносит автора с совокупностью его точек зрения в кругозор своих героев. Фигура Рассветова интересна тем, что в ней отразились основные противоречия американской действительности: восхищение уровнем цивилизации, неприятие Америки как Мировой Биржи и одновременное использование трюков и обмана на пути к собственному обогащению.

Как показывает творчество Есенина тех лет, поэт разделяет ту конечную цель индустриализации и переустройства России, которую преследует Рассветов:

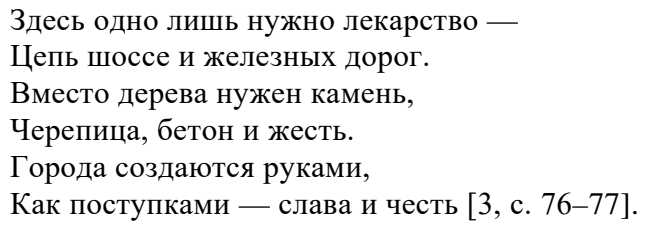

Но что касается поступков, то есть средств, которыми Рассветов добивается построения счастливого будущего, то здесь Есенин явно не разделяет взгляды железного комиссара, теоретика и практика красного террора, и его классовую мораль. Устраивая ловушку повстанцам, которые украли золото, Рассветов, как мы помним. заявляет:

Но только тогда этот вор

Получит свою веревку,

Когда хоть бандитов сто

Будет качаться с ним рядом,

Чтоб чище синел простор

Коммунистическим взглядам [3, с. 102].

${ }^{20}$ Шубникова-Гусева Н.И. Диалог как основа творчества Есенина // Столетие Есенина. Материалы Межд. симпозиума. Есенинский сб. Вып 3. М., 1997. C. 143-144. 
Кроме того, Есенин показывает, что ради личных интересов Рассветов способен пойти на финансовую аферу. Так уже случилось с ним в Клондайке, когда он вместе с золотоискателями участвовал в «биржевом трюке», разорившем многих бизнесменов («Но многие, денежки вхлопав, // Остались почти без брюк») [3, c. 71]. Во вдохновенном монологе Рассветова о ловкости «самого простого прощалыги // Из индианских мест», звучит явное восхищение перед ловкостью, с которой американцы становятся «королями мира». И на законный вопрос Чарина: «Послушай, Рассветов! и что же, // Тебя не смутил обман?» Рассветов отвечает без тени смущенья, полностью раскрывая свои личные амбиции, которые явно превосходят его заботу об окружающих:

Не все ли равно,

К какой роже

Капиталы текут в карман.

Мне противны и те, и эти.

Все они -

Класс грабительских банд.

Но должен же, друг мой, на свете

Жить Рассветов Никандр. [3, с. 72]

Кажется, Рассветова можно оправдать тем, что он говорит про грабительские банды американских бизнесменов. Однако поддерживающие позицию Рассветова три голоса из группы подтверждают, что оправдание обмана, то есть отсутствие совести, находит сторонников в рядах строителей новой России:

Голос из группь

Правильно!

Другой голос

Конечно, правильно!

Третий голос

С паршивой овцы хоть шерсти

Человеку рабочему клок [3, с. 72].

И только совестливый Чарин, который введен в число персонала как будто специально для того, чтобы развенчать политическую демагогию Рассветова и показать нравственное зло, таящееся за революционным пафосом его слов, задает вопрос, разоблачающий главного представителя «руководящего персонала»: «Значит, по этой версии // Подлость подчас не порок?» И не случайно, подчеркивая господство этой подлости в Стране Негодяев, на вопрос Чарина отвечает не сам Рассветов, а первый голос из толпы:

Ну конечно, в собачьем стане,

С философией жадных собак, 
Защищать лишь себя не станет

Тот, кто навек дурак. [3, с. 73]

Еще одна отличительная черта Рассветова, по которой Есенин относит его к Негодяям - он думает не о человеке, а только о строительных материалах: камне, черепице, бетоне и жести. Слово «человек» вообще выпадает из речи персонала Страны Негодяев. Здесь люди становятся индивидами, то есть не хозяевами, а «материалом» истории.

Итак, разгадка сюжета и персонала «Страны Негодяев» кроется в своеобразном типично есенинском зеркальном построении драматической поэмы, при котором следует учитывать не только совпадение, но и несовпадение позиций персонажей поэмы и автора. Драматическая поэма, которую исследователи называют диспутом и спором, является на самом деле спором в споре, диалогом в диалоге, где участвуют не только герои, но и сам автор. Зеркальность как основной принцип построения образа всегда отличала поэзию Есенина. Но здесь поэт использует зеркало как метафору жизни, подобной театру, зеркально выстраивая сюжет, композицию и речь персонажей.

Композиция поэмы строится зеркально к шекспировскому «Гамлету»: Есенин сатирически обыгрывает основные сюжетные мотивы, ключевые сцены, события, образы и речь персонажей «Гамлета» в прямо противоположном смысле. Здесь тоже, как в королевстве Датском «подгнило что-то», и каждый из персонала мечтал быть Гамлетом, а теперь лезет в золотые короли или короли мира.

«Страна Негодяев», как и «Гамлет», открывается сценой смены караула, только в «Гамлете» на смену караула идут «друзья Отечества», а в «Стране Негодяев» - «защитник коммуны», обыватель Замарашкин. Шекспир называет негодяями могильщиков и придворных, от которых остался только череп, а Есенин - «руководящий персонал» мифологической Страны Негодяев. В «Гамлете» песни поет Офелия, а в «Стране Негодяев» подавальщица, кабатчица, тетка Дуня. Центральным событием «Страны Негодяев», как и «Гамлета», является сцена «мышеловки» или ловушки («Мы усилим надзор // И возьмем его, // Как мышь в мышеловку...» говорит о повстанце Номахе комиссар Рассветов).

Бесконечные разговоры персонала «Страны Негодяев» о Гамлете и королях мира или золотых королях получают иносказательный притчевый смысл. Словами Гамлета говорит обыватель Замарашкин: «Слова, слова, слова...» Сравним также обращение к Номаху, почти дословно повторяющее слова Гамлета перед поединком с Лаэртом: «Не завтра, так после... // Не после... Так после опять...» [3, с. 62] (см. действие пятое, сцена II, пер. А. Кроне- 
берга: «Не после, так теперь; не теперь так после; а не теперь, так когда-нибудь да придется же»).

Есенин делает нечто вроде пародии на «Гамлета» и показывает, что «душа, которая хотела быть Гамлетом» уже не современна, ее одолели доллары и бизнес. В «Стране Негодяев» шекспировский подтекст настолько явно выявлен в сюжете и тексте, что определяет жанровое своеобразие поэмы и помогает интерпретировать ее в соответствии с авторским замыслом как сатирический фарс-притчу, который предостерегает об опасности американизации общества и разжигании ненависти и вражды.

Как удалось установить, шекспировский подтекст пришел к Есенину из наиболее популярных в России тех лет переводов «Гамлета» Н.А. Полевого, принятого для школьного изучения, и А. Кронеберга. Но Есенин не переделывает отдельные сцены «Гамлета», а создает совершенно оригинальное произведение, в котором развивает традиции русской классической драмы и, прежде всего, гоголевского «Ревизора». Подобно «сборному» городу в «Ревизоре» (слова Гоголя) Есенин рисует некую «сборную» страну и ее жителей как олицетворенные типы ее обитателей. И подобно Гоголю, Есенин собирает в свою воображаемую Страну Негодяев все дурное, что он видит на родине, которая становится похожей на «Железный Миргород». Автор сатирически разоблачает именно российское негодяйство, в котором находит тот же национальный нигилизм, что и в безродной молодой Америке. «Страна Негодяев» становится поэмой-предостережением, которая показывает не реальную Россию, а ту, какой она может стать, если забудет о собственных национальных интересах и своем народе и увязнет в американском бизнесе и гражданской вражде.

Не случайно это произведение Есенин так и не сумел опубликовать при жизни. Информация о публикации драматической поэмы содержится в «Предисловии» к неизданному собранию стихотворений и поэм 1924 г. [5, с. 222], в 4-м номере журнала «Гостиница для путешествующих в прекрасном» за 1924 год, № 1 (3), а также на макете книги «Москва кабацкая» (1924). Намерение поэта напечатать «Страну Негодяев» в «Собрании стихотворений», которое поэт готовил во второй половине 1925 г., также не осуществилось. Сданный в типографию третий том Собрания не содержал «Страны Негодяев». Лишь благодаря усилиям А.К. Воронского, И.В. Евдокимова и других работников Госиздата эту поэму удалось включить в подготовленный поэтом третий том поэм только после смерти автора, сделав редакционное примечание о ее незавершенности.

Очерк «Железный Миргород» об Америке также подвергся сокращению и правке при подготовке к печати в газете «Известия 


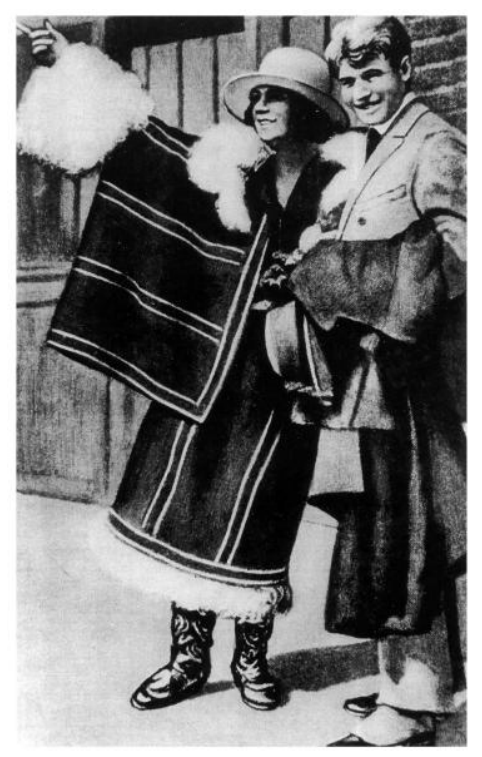

А. Дункан и С.А. Есенин

2 окт. 1922 г. после опроса на о. Эллис-Айленд: «НЕВИНОВНЫ!» (Собр. Г. Маквея)

ЦИК СССР и ВЦИК» ${ }^{21}$. В настоящее время история текста «Железного Мир-города», анализ автографа допечатной редакции (РГАЛИ) и неавторизованной машинописи первой части произведения с сокращениями и поправками рукой редактора (ГА РФ, ф. редакции газ. «Известия»), а также богатые и многообразные источники текста статьи раскрыты в комментариях к Полному собранию сочинений С.А. Есенина [Субботин, 5, с. 399410]. Тем не менее, проблема участия или неучастия Есенина в редакционной подготовке очерка к печати не имеет бесспорного решения. Скорее всего, Есенин согласился на сокращение и правку своего текста вынужденно.

В статье «Железный Миргород» Есенин подчеркивает влияние живых впечатлений: «Я объездил все государства Европы и почти все штаты Северной Америки» [5, с. 161]. С 1 октября 1922 до 3 февраля 1923 г. поэт побывал в Нью-Йорке, Бостоне, Чикаго, Луисвилле, Канзас-сити, Мемфисе, Индианополисе, Кливленде, Толидо и др. Свою статью об американских впечатлениях Есенин строит как травелог, выделяя самостоятельные главки, в названия которых вынесены американские топонимы (названия корабля, на котором он с Дункан прибыл в «страну Колумба», острова, где поэта вместе с женой задержали для «политических экзаменов», города и его главной улицы и др.: «Вот "Paris"» [искаженный английский], «ЭлисАленд», «Нью-Йорк», «Бродвей», «Быт и глубь штатов». Этот очерк заслуживает специального анализа с точки зрения своей художественной выразительности и свойственной Есенину иронии. Но мы в связи с обозначенной нами темой обратим внимание на тот перелом в зрении поэта на Россию и русскую деревню, который совершился под впечатлением «железной и гранитной мощи» Америки.

${ }^{21}$ Известия ЦИК СССР и ВЦИК. М. 1923, 22 авг. и 16 сент. Перепечатка первой части очерка, опубл. в газ. «Новости жизни», Харбин, 1923, 14 сент. с подзаголовком «Американские впечатления Сергея Есенина». 


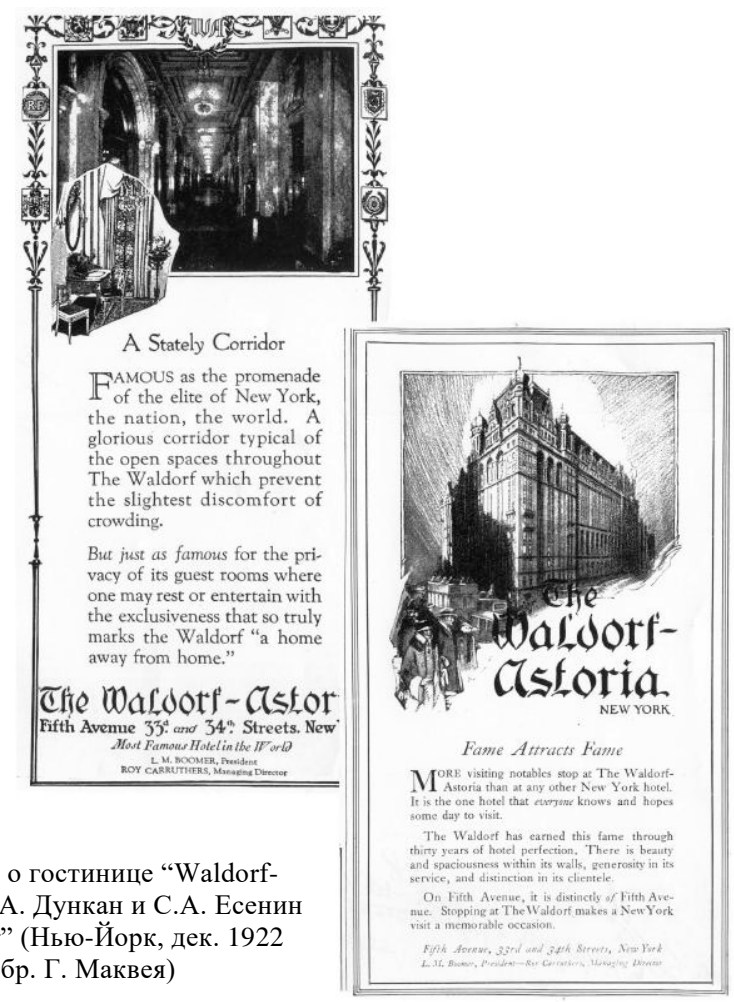

Рекламные объявления о гостинице "WaldorfAstoria”, где поселились А. Дункан и С.А. Есенин из журнала "Vanity Fair" (Нью-Йорк, дек. 1922 и авг. 1923. Собр. Г. Маквея)

В отличие от «Страны Негодяев», где Есенин ведет диалог об Америке с одним из действующих лиц, в «Железном Миргороде» поэт открыто полемизирует со своим основным оппонентом, поэтом Владимиром Маяковским, а также другими писателями-классиками и Л.Д. Троцким. Во всех девяти абзацах, не вошедших в газетную публикацию (выявлено В.А. Вдовиным ${ }^{22}$ ), так или иначе затрагивается американская тема.

Есенин, по собственному определению, «изобретательно выявляет себя», проявляя свою «крайнюю индивидуальность». Чтобы в очередной раз убедиться в этом, обратимся к тексту. Название статьи представляет собой троп, употребление гоголевского образа (сб. «Миргород», 1835) в обратном смысле, который обыгрывается и настраивает на ироничное восприятие текста в целом.

${ }^{22}$ Вдовин В.A. Написано рукой Есенина // Вопросы литературы, 1968, № 7, авг. С. 252-254. См.: Вдовин B.A. Факты - вещь прямая. Труды о С.А. Еceнине / Сост. и предисл. А.А. Вдовина, Н.Г. Юсов. Коммент. Н.Г. Юсов. М.: Новый индекс, 2007. С. 133-136. 
Статья начинается следующими словами: «Я не читал прошлогодней статьи Л.Д. Троцкого о современном искусстве, когда был за границей. Она попалась мне только теперь, когда я вернулся домой. Прочел о себе и грустно улыбнулся. Мне нравится гений этого человека, но видите ли?.. Видите ли?» Речь идет о статье Председателя Реввоенсовета Республики Л.Д. Троцкого (Л.Д. Бронштейна; 1879-1940) «Внеоктябрьская литература: Литературные попутчики революции», где Есенину был посвящен отдельный раздел $^{23}$. Основной заголовок этой газетной публикации (по техническим причинам) был ошибочным (реплику автора по этому поводу см.: Троцкий Л. «Внеоктябрьская литература»: (Необходимая поправка). [Субботин - 5, с. 396]

Слова о гении Троцкого, которые ряд современных исследователи толкуют как восхищение личностью этого человека, на самом деле являются ироничным притворством Есенина, которое обнаруживается благодаря несогласию поэта с его оппонентомполитиком. Статья Есенина по сути является ответом на слова Троцкого о том, что поэт вернется из-за границы «не тем, что уехал»: «Не будем загадывать: приедет, сам расскажет». Есенин отвечает на слова Троцкого, активно вовлекая в диалог Н.В. Гоголя и В.В. Маяковского (конкретные источники полемики указаны С.И. Субботиным в комментарии в статье в Полном собрании сочинений С.А. Есенина).

Через несколько дней после публикации очерка Есенина его слова о Троцком были «обыграны» О.Л. Д’Ором (И.Л. Оршером) в фельетоне-пародии, написанном от лица поэта:

В какой-то газете я прочитал большой фельетон о литературе за подписью какого-то неизвестного мне Л. Троцкого... Надо будет сообщить ему, чтобы он зашел ко мне в «Известия». Думаю поощрить «этого человека». В «этом человеке», кажется, что-то есть ${ }^{24}$.

Характерно, что фельетон И.Л. Оршера был напечатан в московской газете «Правда» вскоре после публикации первой части очерка Есенина в «Известиях» под названием «Сергей Есенин в Америке: Личные воспоминания. Напечатано на правах декрета в «Известиях ЦИКа СССР и РСФСР» с подписью: Списал стенографически О.Л.Д’Ор». Фельетонист едко высмеял созданный Есениным собственный образ и то внимание, которое было оказано Есенину и Дункан по прибытии в Нью-Йорк («сотни кинематографистов и журналистов», «около 20 газет с портретами и огромными статьями о нас»):

${ }^{23}$ Газ. «Правда», М., 1922, 5 окт. Подробнее см. комм. С.И. Субботина [5, c. 396-397].

${ }^{24}$ Газ. «Правда», М., 1923, 28 авг. 

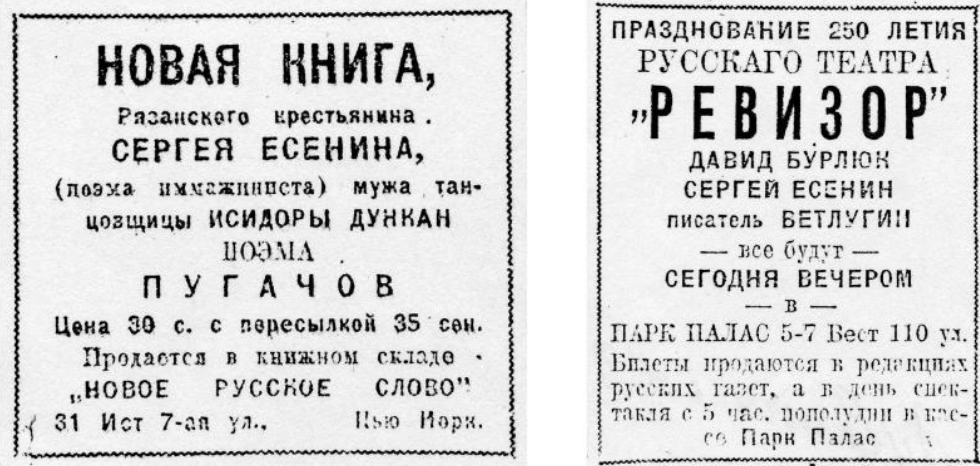

Объявления в газете «Новое русское слово» (Нью-Йорк, 1922, 22 дек.) о поступлении в продажу книги С.А. Есенина «Пугачев» (Берлин, 1922) и о праздновании 250-летия русского театра с анонсом об участии С.А. Есенина

...мое появление в Америке было заранее предсказано Пулковской обсерваторией. Трудно нашему брату, небесному светилу, странствовать инкогнито... [...] Фотографы попросили меня отогнуть немножко от моей лебединой шеи дорогие кружева моего матинэ. Я это сделал и они ослеплены белизной моих плеч и классической правильностью моих форм. [...] Все в один голос решили, что при царском правительстве московские купчики ни за что не выпустили бы из России такого красавца ${ }^{25}$.

Особое внимание фельетонист уделил острым сюжетам, которые касались личных оценок ее автора, среди них было определение Есениным статуи Свободы - «бедная старая девушка, ты поставлена здесь ради курьеза». Внимание автора фельетона к оценкам железной и гранитной мощи Америки и к полемике с Маяковским не проявилось. Только после публикации второй части очерка эмигрант А.М. Селитренников в статье «Мемуары хулигана» критиковал Есенина за то, что тот воздает хвалу «строителям новой “индустриальной культуры”», «систематически» истреблявшим «из года в год русский народ» 26.

Тем не менее, восхищение достигнутой в Америке мощью индустрии переломило зрение Есенина на будущее своей страны:

С того дня я еще больше влюбился в коммунистическое строительство. Пусть я не близок коммунистам как романтик в моих поэмах, — я близок им умом и надеюсь, что буду, быть может, близок и в своем творчестве. [5, с. 163$]$

\footnotetext{
25 Там же.

${ }^{26}$ Газ. «Новое время», Белград, 1923, 26 окт.; подпись: А. Ренников.
} 
Одним из побудительных мотивов к написанию очерка об Америке становятся произведения Маяковского. В первой части очерка «Железный Миргород» содержатся скрытые ироничные параллели с парижскими очерками Маяковского ${ }^{27}$ и прямой выпад в его адрес:

До чего бездарны поэмы Маяковского об Америке! Разве можно выразить эту железную и гранитную мощь словами?! Это поэма без слов. Рассказать ее будет ничтожно. Милые, глупые, смешные российские доморощенные урбанисты и электрификаторы в поэзии! Ваши «кузницы» и ваши «лефы» как Тула перед Берлином или Парижем. [5, с. 163]

В цитируемом тексте содержится намек на поэму Маяковского «150 000 000», в которой отразились американские впечатления Маяковского, полученные им из книг. Маяковский посетит Америку только в 1925-1926 гг., напишет «Стихи об Америке», а в своем очерке «Мое открытие Америки» назовет свою поэму «150 000 000» «выдуманной».

Во второй части «Железного Миргорода» есть такие слова: «...мне смешны поэты, которые пишут свои стихи по картинкам плохих американских журналов» [5, с. 168] в рукописи вместо слова «поэты» читаем «все эти “лефствующие"»; изъято редактором]. Здесь Есенин вступает в полемику с взглядами российских урбанистов («кузницы», «лефы», «лефствующие»), изложенными в декларациях, опубликованных в 1923 г. [5, с. 399] Поэт имеет в виду также тот факт, что в поэме «150 000 000» Маяковский писал об Америке, читая американские журналы, еще не побывав в этой стране («по картинкам»).

Наиболее существенны следующие сокращения первой части допечатного текста:

Народ наш мне показался именно тем 150000000 -ым рогатым скотом, о котором писал когда-то в эпоху буржуазной войны в «Летописи» Горького некий Тальников. Где он теперь? [5, с. 266-267]

Редактор «Известий» вычеркивает текст, в котором заглавие поэмы Маяковского — «150 000 000» соотносится с содержанием статьи Д. Тальникова «При свете культуры (Чехов, Бунин, С. Подъячев, Ив. Вольнов) ${ }^{28}$ и именем М. Горького, как редактора журнала «Летопись», автора получившей в конце 1922 г. шумную извест-

${ }^{27}$ Цикл статей Маяковского о Париже был опубликован «Известиях» в декабре 1922 - марте 1923 гг.: 1) «Париж (Записки Людогуся)» (24 дек.); 2) «Осенний салон» (27 дек.); 3) «Париж: Художественная жизнь города» (13 янв.); 4) «Париж» (2 февр.); 5) «Париж» (6 февр.); 6) «Парижские очерки» (29 марта). См. комм. Субботина [5, с. 395].

28 Журн. «Летопись», Пг., 1916, № 1, янв. С. 275-299. 
ность брошюры «О русском крестьянстве» (Берлин, 1922) ${ }^{29}$. Познакомившись с достижениями современной цивилизации, Есенин ругает всех, цепляющихся за грязь и вшивость, и «желает, чтоб мужик не ходил “до ветру” в чужой огород» [5, с. 267].

Заметим, что в есенинском тексте наряду с безжалостной иронией по отношению к поэме «150 000 000» сквозит явное восхищение некоторыми деталями из парижских очерков Маяковского. Так, Есенин с явной оглядкой на эпизод осмотра паспортов на французской границе из очерка Маяковского «Париж (Записки Людогуся)» описывает аналогичную американскую сцену в «Железном Миргороде»; то же можно сказать, сравнив главку «Бурже» из очерка Маяковского «Париж» и описание громады броненосцев около Нью-Йорка у Есенина; вслед за Маяковским, утверждающим в очерке «Париж (Записки Людогуся)»: «...кажется, [в Париже] есть одна, последняя лошадь, - ее показывают в зверинце» ${ }^{30}$, Есенин пишет в «Железном Миргороде», что «в Нью-Йорке лошади давно сданы в музей...» [5, с. 168]. В связи с этой темой в продолжении фразы о лошадях появляются ироничные строки о вожде: «но в наших родных пенатах я даже и самого гениального электрофикатора Ленина видел в Петербурге на жалком тарантасе с лицом, упертым в почтенный зад кобылы» [5, с. 273]. Не удивительно, что строки о Ленине также не попали в печать.

Характерно, что во второй части очерка «Железный Миргород» ни одна из прямых и косвенных перекличек с Маяковским в печатный текст не попала. Сравнение рукописного текста с опубликованным в газете, а также воспоминания помощника секретаря редакции «Известий» В.М. Василенко дают основание предположить, что вторая часть текста потребовала еще более кропотливой редакторской работы, чем первая. В тексте второй части очерка, не вошедшем в публикацию, Есенин иронически переосмысливает название поэмы Маяковского: в тогдашнем, и в нынешнем просторечии слово «лимон» означает «миллион рублей»:

У какого-то смешного поэта, написавшего «сто пятьдесят лимонов», есть строчки о Чикаго как символе Америки: «Пройдешь:

За ступней ступня

${ }^{29}$ См. Субботин С.И. Есенин. Россия. Народ // Российская провинция. М., 1995, № 4. С. 26. Здесь же автор статьи обращает внимание на слова М. Горького о «тяжелом русском народе, лениво, нерадиво и бесталанно лежавшем на своей земле», о народе, «который ухитрился жить изумительно нищенски на земле, сказочно богатой».

${ }^{30}$ Маяковский В.В. Полн. собр. соч. В 13 т. М.: Худ. лит. 1955-1961. Т. 4. 1957. C. 208. 


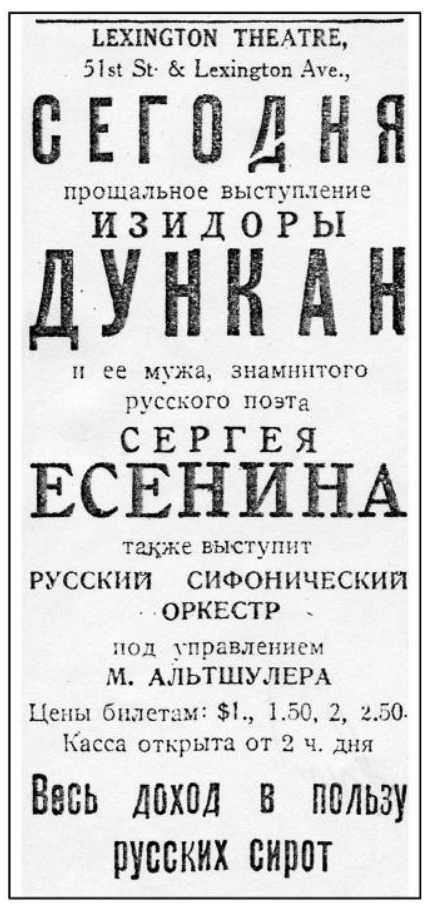

Объявление о выступлении

А. Дункан и С. Есенина в пользу русских сирот. Нью-Йорк, Lexington Theatre, 2 февр. 1923 г. $[\ldots]^{31}$

И еще ступня,

Ступеней этих самых до чёртиков». 31

Правда! Оно, положим, и есть ступени, но никто по ним не ходит, потому что ступени эти «чёртиковы» существуют только на пожарные случаи, а подымаются там исключительно в лифтах в 3-4 секунды до 46 этажа. Так что по картинкам иногда можно ошибиться и нечаянно дать Америку, перелагая Уитмана, 19-го века, Америку старого Нью-Йорка. Тогда Бродвей был не таким. [5, с. 273-274, 409; подчеркнуты слова, изъятые из печатного текста].

Внешне несогласие Есенина с Маяковским выражается в том, что тот еще не был в Америке:

Нужно пережить реальный быт индустрии, чтобы стать ее поэтом. [...] Сила Америки развернулась окончательно только за последние двадцать лет. [...] Когда все это видишь или слышишь, то невольно поражаешься возможностям человека, и стыдно делается, что у нас в России верят до сих пор в деда с бородой и уповают на его милость. [5, с. 168-169]

Но «громадная культура машин, которая создала славу Америке, по словам Есенина, - есть только результат индустриальных творцов», а не гения и культуры американцев, у которых все стремления съело «владычество доллара». Отсутствие внутренней духовной культуры и интереса к искусству, которое находится «на низшей ступени развития» - вот то, с чем не может примириться Есенин в Америке, которая становится для него в конечном счете «символом убогого бескультурья и духовного застоя» ${ }^{32}$. Одним из наиболее убедительных подтверждений низкой культуры развития в Америке Есенин находит в том, что «там до сих пор остается неразрешимым вопрос: нравственно или безнравственно поставить памятник Эдгару По» [5, с. 170].

${ }^{31}$ Есенин приводит отрывок из поэмы Маяковского «150 000 000» по памяти и в сокращении.

32 Повицкий Л.И. Сергей Есенин в жизни и творчестве // С.А. Есенин в воспоминаниях современников. Т. 2. С. 243. 
Позже, в автобиографии 1924 г. Есенин еще раз подчеркнет свой изменившийся взгляд на будущее России:

После заграницы я смотрю на страну свою и события по-другому. Наше едва остывшее кочевье мне не нравится. Мне нравится цивилизация, но я очень не люблю Америки. Америка - это тот смрад, где пропадает не только искусство, но и вообще лучшие порывы человечества.

Если сегодня держат курс на Америку, то я готов тогда предпочесть наше серое небо и наш пейзаж: изба немного вросла в землю, прясло, из прясла торчит огромная жердь, вдалеке машет хвостом на ветру тощая лошаденка. Это не то, что небоскребы, которые дали пока что только Рокфеллера и Маккормика, но зато это то самое, что растило у нас Толстого, Достоевского, Пушкина, Лермонтова и др. ${ }^{33}$

\section{ЛИТЕРАТУРА}

Арустамова А.А. Тема Америки в русской литературе XIX в.: дисс. ... докт. филол. наук. Пермь, 2010.

Вдовин B.A. Написано рукой Есенина // Вдовин B.A. Факты - вещь прямая. Труды о С.А. Есенине / Сост. и предисл. А.А. Вдовина, Н.Г. Юсов. Коммент. Н.Г. Юсов. М.: Новый индекс, 2007. С. $133-136$.

Воронова O.E. Наследие Есенина и эволюция национальной идеи в русском художественно-философском сознании // Наследие Есенина и русская национальная идея: современный взгляд. Материалы междун. научной конференции / ред. О.Е. Вороновой; А.Н. Захарова. Рязань: Рязанский гос. пед. ун-т им. С.А. Есенина, 2005. С. 5-27.

Воронова О.Е. Сергей Есенин и русская духовная культура. Рязань: Узорочье, 2002.

Воронский А.К. Литературные силуэты. Сергей Есенин // Красная новь. 1924, № 1. С. 278, 289.

Еременко Н.A. Американская тема в творчестве С.А. Есенина: поэтика и контекст: дис. ... канд. филол. наук. М., 2015.

Есенин С.А. Полн. собр. соч. В 7 т. (9 кн.) / гл. ред. Ю.Л. Прокушев. М.: НаукаГолос. 1995-2002.

Зверев А.М. Сергей Есенин в Америке // В мире Есенина: сб. ст. / сост. А.А. Михайлов, С.С. Лесневский. М.: Сов. писатель, 1986. С. 361-375.

Кубанев Н.А. Образ Америки в русской литературе: (из истории русско-американских литературных связей конца XIX - первой половины XX века). М.: Гуманит. ун-т; Арзамас: Арзамас, гос. пед. ин-т, 2000.

Кэмрад С. Маяковский в Америке. Страницы биографии. М.: Сов. писатель, 1970.

Летопись жизни и творчества С.А. Есенина. В 5 т. 7 кн. М.: ИМЛИ РАН, 20022018. [Последний том в производстве].

Маяковский В.В. Полн. собр. соч.: В 13 т. / АН СССР. Ин-т мировой лит. им. А.М. Горького. М.: Гос. изд-во худож. лит., 1955-1961.

${ }^{33}$ Есенин С. Полн. собр. соч. / Ин-т мировой лит. РАН / Гл. ред. Ю.Л. Прокушев. Т. 7. Кн. 1 / Сост., подгот. текстов и коммент. А.Н. Захаров, С.П. Кошечкин, Т.К. Савченко, М.В. Скороходов, С.И. Субботин, Н.Г. Юсов. М.: Наука; Голос. 1999. С. 17. 
Михайлов K. Рецепция нового мира у Сергея Есенина («Железный Миргород») и Алеко Константинова («До Чикаго и обратно») // Сергей Есенин и русская история. Сб. трудов по материалам Международной научной конференции, посвященной 117-летию со дня рождения С.А. Есенина и Году российской истории. Москва-Рязань-Константиново. - 2013. С. 81-90.

Николюкин А.Н. Взаимосвязи литератур России и США: Тургенев, Толстой, Достоевский и Америка. М.: Наука, 1987.

Пономарев E.P. Типология советского путешествия. «Путешествие на Запад» в русской литературе 1920-1930-х годов: дисс. ... докт. филол. наук. СПб., 2014.

Русское зарубежье о Есенине. Воспоминания, эссе, очерки. Рецензии, статьи: в 2 т. / Вступ. ст., сост., коммент. Н.И. Шубниковой-Гусевой. М.: Инкон, 1993.

Сафронов А.В. Американская тема в публицистике А.С. Пушкина и С.А. Есенина // «Что скажет о тебе далекий правнук твой»: межвуз. сб. науч. тр. / отв. ред. И.В. Грачева. Рязань: Рязан. гос. пед. ун-т им. С. А. Есенина, 1999. С. 59-62.

С.А. Есенин в воспоминаниях современников: В 2 т. / вступ. ст., сост. и коммент. А. Козловского. М.: Худ. лит., 1986.

Субботин С.И. Библиотека Сергея Есенина // Есенин на рубеже эпох: итоги и перспективы: Материалы международной конференции, посвященной 110-летию со дня рождения С.А. Есенина. Рязань: Пресса, 2006. С. 331-355.

Субботин С.И. Есенин. Россия. Народ // Российская провинция. М., 1995, № 4. C. $22-31$.

Шубникова-Гусева Н.И. Диалог как основа творчества Есенина // Столетие Есенина. Материалы Межд. симпозиума. Есенинский сб. Вып 3 / Ред.-сост. А.Н. Захаров, Ю.Л. Прокушев. М., 1997. С. 130-159.

Шубникова-Гусева Н.И. Маяковский и Есенин: диалог поэтов // Творчество В.В. Маяковского. Вып. 2: Проблемы текстологии и биографии. М.: ИМЛИ РАН. 2014. C. $198-223$.

Шубникова-Гусева Н.И. Поэмы Есенина: От «Пророка» до «Черного человека»: Творческая история, судьба, контекст и интерпретация / Н.И. Шубникова-Гусева. М.: «Наследие», 2001.

McVay Gordon. «Isadora and Esenin». Ann Arbor, MI: Ardis, 1980.

\section{REFERENCES}

Arustamova A.A. Tema Ameriki v russkoj literature XIX v.: diss. dokt. filol. nauk. Perm', 2010.

Eremenko N.A. Amerikanskaja tema v tvorchestve S.A. Esenina: pojetika i kontekst: diss. ... kand. filol. nauk. M., 2015.

Esenin S.A. Polnoe sobranie sochinenii: in 7 vols. (9 books), ed. Yu.L. Prokushev. Moscow: Nauka-Golos publ., 1995-2002.

Kemrad S. Majakovskij v Amerike. Stranicy biografii. Moscow: Sovetskii pisatel' publ., 1970.

Kubanev N.A. Obraz Ameriki v russkoj literature: (iz istorii russko-amerikanskih literaturnyh svjazej konca XIX - pervoj poloviny XX veka). Moscow: Gumanitarny universitet publ.; Arzamas: Gos. Ped. Institute publ., 2000.

Letopis' zhizni i tvorchestva S.A. Esenina: in 5 vols (7 books). Moscow: IMLI RAN publ., 2002-2018. [The last volume in print].

Majakovskij V.V. Polnoe sobranie sochinenii: in 13 vols. Moscow: Gos. izd-vo hudozh. lit. publ., 1955-1961.

Mihajlov K. "Recepcija novogo mira u Sergeja Esenina («Zheleznyj Mirgorod») i Aleko Konstantinova («Do Chikago i obratno»).” Sergej Esenin i russkaja istorija. Sb. tru- 
dov po materialam Mezhdunarodnoj nauchnoj konferencii, posvjashhennoj 117-letiju so dnja rozhdenija S.A. Esenina i Godu rossijskoj istorii. Moscow; Rjazan'; Konstantinovo, 2013: 81-90.

McVay Gordon. Isadora and Esenin. Ann Arbor, MI: Ardis, 1980.

Nikoljukin A.N. Vzaimosvjazi literatur Rossii i SSHA: Turgenev, Tolstoj, Dostoevskij i Amerika. Moscow: Nauka publ., 1987.

Ponomarev E.R. Tipologija sovetskogo puteshestvija. «Puteshestvie na Zapad»v russkoj literature 1920-1930-h godov: diss. dokt. filol. Nauk. St.-Petersburg, 2014.

Russkoe zarubezh'e o Esenine. Vospominanija, jesse, ocherki. Recenzii, stat'i: in 2 vols, introd., comp., ed. comm. N.I. Shubnikova-Guseva. Moscow: Inkon publ., 1993.

S.A. Esenin v vospominanijah sovremennikov: in 2 vols., introd., cpmp. comm. A. Kozlovsky. Moscow: Khud. lit. publ., 1986.

Safronov A.V. "Amerikanskaja tema v publicistike A.S. Pushkina i S.A. Esenina." "Chto skazhet o tebe dalekij pravnuk tvoj”: mezhvuz. sb. nauch. tr., ed. I.V. Gracheva. Rjazan': Rjazan. gos. ped. un-t im. S.A. Esenina publ., 1999: 59-62.

Shubnikova-Guseva N.I. "Dialog kak osnova tvorchestva Esenina." Stoletie Esenina. Materialy Mezhd. simpoziuma. Eseninskij sb. Issue 3, eds. A.N. Zaharov, Ju.L. Prokushev. Moscow, 1997: 130-159.

Shubnikova-Guseva N.I. "Majakovskij i Esenin: dialog pojetov." Tvorchestvo V.V. Majakovskogo. Vypusk vtoroj: Problemy tekstologii i biografii. Moscow: IMLI RAN publ., 2014: 198-223.

Shubnikova-Guseva N.I. Poemy Esenina: Ot "Proroka" do "Chernogo cheloveka": Tvorcheskaja istorija, sud'ba, kontekst i interpretacija. Moscow: Nasledie publ., 2001.

Subbotin S.I. "Biblioteka Sergeja Esenina." Esenin na rubezhe jepoh: itogi $i$ perspektivy: Materialy mezhdunarodnoj konferencii, posvjashhennoj 110-letiju so dnja rozhdenija S.A. Esenina. Rjazan': Pressa publ., 2006: 331-355.

Subbotin S.I. "Esenin. Rossija. Narod.” Rossijskaja provincija. Moscow, 1995, № 4: 22-31.

Vdovin V.A. "Napisano rukoj Esenina.” Vdovin V.A. Fakty — veshh' prjamaja. Trudy o S.A. Esenine, eds. A.A. Vdovin, N.G. Jusov, comm. N.G. Jusov. Moscow: Novyj indeks publ., 2007: 133-136.

Voronova O.E. "Nasledie Esenina i jevoljucija nacional'noj idei v russkom hudozhestvenno-filosofskom soznanii." Nasledie Esenina i russkaja nacional'naja ideja: sovremennyj vzgljad. Materialy mezhd. nauchnoj konferencii, eds. O.E. Voronova, A.N. Zaharova. Rjazan': Rjaz. gos. ped. un-t imeni S.A. Esenina publ., 2005: 5-27.

Voronova O.E. Sergej Esenin i russkaja duhovnaja kul'tura, ed. O.E. Voronova. Rjazan': Uzoroch'e publ., 2002.

Zverev A.M. "Sergej Esenin v Amerike." V mire Esenina, eds. A.A. Mihajlov, S.S. Lesnevskij. Moscow: Sovetskii pisatel' publ., 1986: 361-375. 